\title{
Genel Müzik Eğitiminde Türk Müziği Unsurlarının Öğretilmesine Yönelik Çalgı Boyutuna İlişkin Öğretmen Görüşleri
}

\author{
Teachers' Views on Instrument Dimension for Teaching Turkish Music Elements in General Music \\ Education
}

\author{
Hamza Üstün* - Aytekin Albuz ${ }^{* *}$
}

\begin{abstract}
The aim of this study is to determine the opinions of teachers regarding the Turkish music teaching and instrument education dimensions in music education, which is called general music education and starts from pre-school period and continues to the end of high school education. A total of 1321 teachers working in private or public institutions under the Ministry of National Education throughout Turkey participated in the study. The questionnaireform created by taking the opinions of field experts ( 5 person) by the researcher, was sent to the teachersarticipating in the study through social platforms and electronic media. Through the survey; in terms of instrument education, it was tried to determine the enstrument usage situations of teachers in music lessons and their applications in the field of Turkish music. The content validity index validity measurement developed by Lawshe was performed to determine the content and scope validity of the questionnaire regarding its evaluation by the experts. Lawshe content validity index is determined as 0,867. In addition, Crombach Alpha test was used for the internal consistency and homogeneous structure of the questions. CrombachAlpha coefficient was found .74. In the result of the Kaiser-Meyer-Olkin test applied to determine the validty and reliability of the measurement tool, the KMO value was determined as .875 . According to the research results; related to instrument education and Turkish music teaching; students indifference to Turkish music issues, the insufficiency of existing school instruments, the inclusion of the instrument leaarning area in the re-education program, a new systematic approach to Turkish music teaching are needed, and the insufficiency of the sections related to Turkish music teaching in the curriculum is emphasized.
\end{abstract}

Structured Abstract: Introduction and Purpose: In our country, music education is given in private and public institutions under the Ministry of National Education starting from pre-school period until the end of high school education. Courses are carried out within the music curriculum published by MEB. (MEB,2018).

\footnotetext{
* Doktora Öğrencisi, Gazi Üniversitesi Eğitim Bilimleri Enstitüsü. PhD Student, Gazi University Institute of Education Sciences. ORCID 0000-0001-8084-7946 ustunhamza@gmail.com

** Prof. Dr., Gazi Üniversitesi Eğitim Fakültesi Güzel Sanatlar Eğitimi Bölümü Müzik Eğitimi Anabilim Dalı Prof. Dr.Gazi Universty Education Faculty Department of Fine Arts Music Education Department ORCID 0000-0001-7919-0596 aalbuz@gmail.com

Cite as/ Atıf: Üstün, H. \& Albuz, A. (2020). Genel müzik eğitiminde Türk müziği unsurlarının öğretilmesine yönelik çalg1 boyutuna ilişkin öğretmen görüşleri. Turkish Studies - Education, 15(3), 2191-2209. https://dx.doi.org/10.29228/TurkishStudies.42222

Received/Geliş: $20 \mathrm{March} /$ Mart 2020

Accepted/Kabul: 21 June/Haziran 2020

Copyright (C) INTAC LTD, Turkey

Checked by plagiarism software

Published/Yayın: 25 June/Haziran 2020

CC BY-NC 4.0
} 
Purpose of the research; the determination of the opinions of music teachers about instrument education / teaching in Turkish music applications that they apply in their lessons. In line with this purpose, it was aimed to identify the problems experienced in Turkish music practices of the music teachers who carry out their courses determined with the curriculum and to propose solutions to these problems.

The problem statement of the research is, "What are the teachers' views on the instrument dimension for teaching Turkish music elements in general music education?" In the light of the main problem identified, answers to the following sub-problems were sought.

1. What are the opinions of teachers about Turkish music teaching in general music education?

2. What are the opinions of teachers about the instrument size in general music education?

3. Do teachers' opinions about teaching Turkish music elements in general music education and instrument size in Turkish music applications differ according to their professional experience?

4. What are the contributions and opinions of teachers to the study other than the questionnaire?

\section{Method}

This research is a descriptive study in the screening model for determining the opinions of music teachers about the size of the instrument in teaching Turkish music elements in their lessons. Scanning models are researches that try to describe a situation that exists in the past or present as it exists. The subject of the research is tried to be described in its own conditions and as it is (Karasar,1998). The study group, created in 1321 is a music teacher who works in public and private institutions in Turkey. The data was sent to the teachers participating in the study through the application of google forms through social platforms.

The data in the study were provided with a questionnaire form aimed at determining the opinions of the teachers about the instrument size of Turkish music teaching developed by the researcher. The questionnaire is collected under three main headings. The first one is the demographic question consisting of a single question. As the second part, there are questions consisting of a total of 15 questions and 5-point Likert-type expression types. The last section includes an open-ended section where teachers can write their opinions about the study.

Lawshe content validity index was determined as 0.867. In addition, Crombach alpha coefficient was found to be .74 in the analysis regarding the reliability of the questionnaire form, which is the measurement tool of the study. After ensuring the validity of the scope, Kaiser-Meyer-Olkin KMO test was applied to determine the validity and reliability of the measuring tool. The KMO value of the measuring tool was determined as .875 .

SPSS 22 program was used for statistical analysis of the data. In the analysis of the findings obtained, frequency (f), percentage $(\%)$, average $(\overline{\mathrm{x}})$ and standard deviation (ss) values were interpreted through the tables.

\section{Findings}

When the distribution of the opinions of teachers about Turkish music teaching in their lessons is analyzed, the highest average ( $\bar{x}: 4.09$, ss: .960) should also be organized in terms of Turkish / Western music teaching, while the lowest average ( $\mathrm{x}: 2.61$, ss: 1.182) students' interest in Turkish music was determined as their level. Statistical explanations of the answers given to the questions about Turkish music teaching are included. The total average value of this section consisting of 8 questions is determined as $\overline{\mathrm{x}}$ : 3,26. The standard deviation was calculated as ss: 1,114 . It can be said that the teachers who participated in the study participated in the answers they gave about the teaching of Turkish music with a general expression $(\overline{\mathrm{x}}: 3,26)$.

In the lessons of the music teachers who participated in the study, opinions about the instrument size related to Turkish music applications were explained. In the light of this information, with the highest average of teachers' opinions ( $\mathrm{x}: 4.30$ ss: .945), the question of instrument teaching is an important dimension in music education, and the lowest average ( $\bar{x}: 2,11$ ss: 1,199$)$ as recorder school instrument in music lessons. It is determined as the question is sufficient. The total average value of this section consisting of 7 questions was determined as $\overline{\mathrm{x}}: 3.60$ and standard deviation as ss: 1.094. It can be concluded that a total of n: 1321 
teachers who participated in the study participated in the answers they gave about instrument education with a general expression ( $\bar{x}: 3,60)$.

ANOVA test was applied to determine whether the information about Turkish music teaching used by teachers in their lessons, information obtained about instrument education, professional experience of teachers and the differences between them. According to Levene homogeneity results, which is the first stage of the test, $\mathrm{p}<0.05$, there is no homogeneous distribution between the groups. In cases where homogeneity was not achieved between the groups, Brown-Forsythe F and Welch's tests were applied. Since the homogeneity, which is the prerequisite of the Anova test, is not achieved, p value was found less than 0.05 in the results obtained from Welch and Borwn-Forsythe tests.

\section{Conclusions and Recommendations}

As a result, in line with the answers received from a total of 1321 teachers who participated in the study, related to Turkish music and instrument teaching;

- The parts of the curriculum related to Turkish music are insufficient,

- The majority of teachers cannot use Turkish music instruments,

- Recorder is not sufficient as a school instrument and there is a need for an instrument where Turkish music and tonal music can be played simultaneously,

- Although instrument teaching has been removed from the curriculum, it is still used frequently by teachers,

- Teachers have difficulties while teaching microtonal sounds,

- The academic studies on Turkish music teaching are insufficient,

- Teachers need in-service training,

- New systematic approach is needed for Turkish music teaching,

- It has been concluded that students' interest in Turkish music is low.

It is thought that revising and revising the relevant sections of the curriculum will contribute to learning. Instrument learning area should be included in the curriculum and renewed. It is necessary to change our teaching methods and techniques in order to increase our students' interest in Turkish musicrelated subjects and accordingly, the curriculum should be reshaped.

Keywords: Music, General Music Education, Instrument Education, Turkish Music Teaching, Curriculum

Öz: Bu çalıșmanın amacı, ülkemizde okul öncesi dönemden başlayıp lise öğrenimi sonuna kadar devam eden ve genel müzik eğitimi olarak adlandırılan müzik eğitiminde, Türk müziği öğretimi ve çalg1 eğitimi boyutlarına ilişkin öğretmen görüşlerinin belirlenmesidir. Araştırmaya Türkiye genelinde Milli Eğitim Bakanlığına bağlı özel ya da resmi kurumlarda görevli toplam 1321 öğretmen katılmıștır. Araștırmacı tarafından alan uzmanı (5 kişi) görüşleri alınarak oluşturulan anket formu, çalışmaya katılan öğretmenlere sosyal platformlar ve elektronik ortamdan ulaştırılmıştır. Anket aracılığıyla; çalg1 eğitimi boyutunda öğretmenlerin müzik derslerinde enstrüman kullanım durumları ve Türk müziği alanındaki uygulamaları tespit edilmeye çalışılmıştır. Anket formunun uzmanlar tarafından değerlendirilmesine yönelik içerik ve kapsam geçerliliğini belirlemek için Lawshe tarafından geliştirilen içerik geçerlilik endeksi geçerliliği ölçümü yapılmıştır. Lawshe içerik geçerlilik endeksi 0,867 olarak belirlenmiştir. Ayrıca soruların iç tutarlılığı ve homojen yapısı için Crombach Alpha testi uygulanmıştır. Crombach Alpha katsayısı .74 olarak bulunmuştur. Ölçme aracının geçerlik ve güvenilirliğini belirlemek için uygulanan Kaiser-Meyer-Olkin testi sonuçlarında KMO değeri .875 olarak belirlenmiştir. Araştırma sonuçlarına göre; çalgı eğitimi boyutuna ve Türk müziği öğretimi ile ilgili; öğrencilerin Türk müziği konularına olan ilgisizlikleri, mevcut okul çalgılarının yetersizliği, çalgı öğrenme alanının tekrar öğretim programına dahil edilmesi, Türk müziği öğretimi ile ilgili yeni bir sistematik yaklaşıma ihtiyaç duyulduğu, öğretim programında Türk müziği öğretimi ile ilgili bölümlerin yetersizliği vurgulanmıştır.

Anahtar Kelimeler: Müzik, Genel Müzik Eğitimi, Çalgı Eğitimi, Türk Müziği Öğretimi, Öğretim Programı 


\section{Giriş}

Ülkemizde Milli Eğitim Bakanlığı'na bağl1 özel ve resmi kurumlarda okul öncesi dönemden başlayarak lise öğreniminin sonun kadar müzik eğitimi verilmektedir. Okul öncesi ve ilkokul evresinde dersleri sınıf öğretmenleri, ortaokul ve lise evresinde ise müzik öğretmenleri dersleri yürütmektedir. İlkokul ve ortaokul da müzik dersleri haftada 1 saat ve tüm öğrenciler için zorunlu tutulurken, lise evresinde ders haftada 2 saat ancak seçmeli olarak yer almaktadır. Öğrenciler görsel sanatlar ile müzik dersi arasında seçim yapmak zorundadırlar.

Dersler MEB tarafindan yayımlanan müzik öğretim programı dâhilinde yürütülmektedir. Öğretim programında 2018 yılında yapılmış olan güncelleme ile öğrenim alanları içerisinde bulunan çalgı öğrenme alanı programdan çıkartılmıştır. Yeni öğretim programında temel öğrenme alanları, müzik kültürü, müziksel yaratıcılık, dinleme-söyleme, müziksel algı ve bilgilenme, olarak belirlenmiştir (MEB,2018).

Öğretim programının ilkokul ve ortaokul evresinde özel amaçları;

- Duygu, deneyim ve düşüncelerini müzik yoluyla ifade etmelerine imkan sağlamak,

- Yerel, bölgesel, ulusal ve uluslararası müzik türlerini tanıyarak farklı kültürlere ait öğeleri zenginlik olarak algılamasını sağlamak,

- Bireysel ve toplu olarak nitelikli farklı türlerde şark1 söyleme ve dinleme etkinliklerine katılımlarını sağlamak,

- Milli birliğimizi, bütünlüğümüzü pekiştiren ve dünya ile bütünleşmemizi kolaylaştıran müzik kültürü ve birikimine sahip olmalarını sağlamak maddeleri belirtilmiştir (MEB,2018).

Lise öğrenimindeki amaçlar ise;

- İstiklâl Marşı'mızla beraber millî birlik ve bütünlüğümüzü pekiştiren diğer marşlarımızı doğru ve etkili seslendirmeleri,

- Müzik alanında yapılan çalışmaları ve gelişmeleri takip etmeleri,

- Müziğe yönelik olumlu tutum sergileyerek özgüvenini ve yaratıcılığını geliştirmeleri,

- İlgi ve yeteneği doğrultusunda müzik etkinliklerine (şarkı söyleme, yaratıcı çalışmalar, araştırma) yönelmeleri,

- Müziksel bilgi, görgü, ilgi, istek ve yeteneklerini geliştirmeleri,

- Müzik terminolojisini ve dilini doğru kullanmaları,

- Müziksel alg1 ve bilgilenme ile müziksel temel okuma ve yazma becerisine sahip olmaları,

- Müziğin diğer sanat dallarıyla ilişkisini kurarak estetik duygularını geliştirmeleri,

- Bilinçli bir müzik dinleyicisi olmaları,

- Müzik dağarcığı oluşturmaları,

- Ülkemizdeki müzik türlerini ve önemli sanatçıları tanımaları,

- Evrensel bir müzik kültürüne sahip olmaları olarak belirtilmiştir (MEB,2018).

Belirtilen bu özel amaçlar doğrultusunda öğrenme alanları ve kazanımlar oluşturulmuştur.

\section{Genel Müzik Eğitimi}

Müzik eğitimi belirlenen amaçlar ve hedef kitleye yönelik olmak üzere üç temel alan altında toplanmaktadır. Düzeyi ve kapsamının hangi seviyede olduğuna bakılmaksızın müzik eğitimi, bir çerçeve dâhilinde bütün halinde, amaçları bakımından üç türe ayrılır (Uçan,2005).

$\mathrm{Bu}$ üç ana tür, genel, özengen ve mesleki müzik eğitimidir. Genel müzik eğitimi "Işsmeslek, okul, bölüm, kol-dal ve program türü ne olursa olsun, ayırım gözetmeksizin, her düzeyde, her aşamada, her yaşta herkese yönelik olup, sağlıklı ve dengeli bir insanca yaşam için gerekli asgari-ortak genel müzik kültürünü kazandırmayı amaçlar"(Uçan,2005). Ülkemizde de MEB 
tarafından yayımlanan öğretim programı çerçevesinde gerçekleştirilen eğitim, genel müzik eğitimi olarak adlandirılır.

\section{Çalgı Eğitimi}

Öğretim programında belirlenen hedefler doğrultusunda ilerleyen, öğrencilerin bireysel farklı1ıklarını göz önüne alan çalgı eğitimi süreci olarak adlandırılabilir. Çoban (2011) çalgı çalma sürecini " Bir çalgıyı çalmak için gerekli olan bütün becerilerin sistematik bir şekilde kazanılmasını kapsayan uzun soluklu bir süreç" olarak nitelendirmiştir.

"Çalg1 eğitimi insanın kendisini yakından tanıyabilmesi, var olan yeteneklerini anlayabilmesi, eğitim arcıllğ sayede kendisini gerçekleştirebilme şansı veren bir uğraş olmasından dolayı müzik eğitiminin önemli bir koludur" (Uslu'dan aktaran Çakırer, Kınık,2014) diyerek, öğrenme alanları içerisindeki çalgı öğretiminin önemini vurgulamıştır.

Bireylerin müziksel davranışlarında olumlu yönde katkıları olan çalgı eğitimi ayrıca bireylerin sosyal gelişimine de katkılar sağlamaktadır. Müzik öğretim programlarında 2018 yılına kadar öğrenme alanları içerisinde bulunan çalgı alanı MEB tarafindan yayımlanan son program ile birlikte ana öğrenme alanları içerisinden çıkartılmıştır. Öğretmenler kendi belirledikleri program dahilinde sınıflarında istedikleri bir çalgı ile eğitim faaliyetlerine devam edebilmektedirler.

\section{Okul Çalgıları}

"Çalg1 eğitimi; bir ya da birden çok çalgının kullanılmasıyla, genellikle bireysel, bazen de toplu olarak yapılan, bireyi çalgı aracılığıyla yetiştirme, geliştirme, müzik alanında ve müziksel anlamlarda içeriği bulunan istendik davranışlar hedeflenen ölçüde kazandırabilme eğitimi olarak nitelendirilebilir" (Kurtuldu' dan aktaran Karataş, Kılıç,2017).

Bozkaya (2001) çalışmasında kullanılabilecek okul çalgılarını, gitar, blokflüt, elektronik org, bağlama, melodika, piyano ve mandolin olarak sınırlandırmıştır. Bu çalgıların yanında günümüzde sıklıkla kullanılan orff çalgılarını da eklemek mümkündür. Orff çalgıları çubuklu çalgılar metalofon, ksilofon, glockenspiel, kariyon, derili çalgıları def, bongo, davul, el trampeti kasnaklı trampet, büyük trampet, ritim çalgıları kastanyet, zil, ritim çubukları, ahşap blok trampet ritim kutusu, marakas, dil trampeti, çelik üçgen, kaynana zırıltısı, kazımalı sürtmeli çalgılar (Ekici, 1998: 31) olarak ayrilmıştır.

\section{Müzik Derslerinde Türk Müziği Öğretimine Yönelik İçerik İncelemesi}

2018 yılında güncellenen müzik dersi öğretim programları (MEB,2018) incelenmesi sonucunda, müzik derslerinde Türk müziği öğretimine yönelik içerikler belirlenmiştir. Bu içerikler doğrultusunda, İlkokul birinci sınıfta Türk müziği uygulamaları, şarkılara ritmik vücut hareketleri ile eşlik etmek ve türküleri söylemek şeklinde yer almaktadır. Türk müziği enstrümanları tanıtılır ve bu çalgılar ile ilgili etkinlikler yapılır. İkinci sınıfa gelindiğinde ise, Türk müziği uygulamaları türkülerimiz, müzik türlerimiz ve çalgılar üzerine yoğunlaşmıştır. Vurmalı çalgılar, telli çalgılar, üflemeli çalgılar ve vurmalı ezgili çalgılar olarak ayrılan çalgı gruplarının resimleri ile beraber gösterilerek etkinlikler düzenlenmiştir. Müzik türleri ünitesinde ise, geleneksel müzik türlerimizden Türk halk müziği, mehter müziği ve Türk sanat müziğine yer verilmiştir. Tüm bu türlere ait eserler örnekleri ile birlikte gösterilmektedir.

Üçüncü sınıfa gelindiğinde Türk müziği uygulamaları çalgılar, halk oyunlarımız ile bu oyunların müzikleri ve geleneksel müziklerimizden Türk halk ve sanat müziğinden oluşmaktadır. Çalgılar konusu ile ilgili bir bulmaca etkinliği yer almaktadır. Halay, zeybek, kaşık, horon, bar, karşılama, teke ve hora oyunları bölgelerin müzikleri eşliğinde yer alır. Geleneksel müziklerimiz ile ilgili de Türk halk müziği ve sanat müziği ile ilgili örneklere yer verilmiştir. Dördüncü sınıfta müzik kültürü konusu içerisinde çok sesli Türk müziği, Türk sanat müziği, Türk halk müziği, ve 
popüler Türk müziği konularına yer verilmiştir. Belirtilen müzik türleri derinlemesine incelenmiş, geniş örneklendirmeler ile de açıklanmaya çalışılmıştır.

Ortaokul evresine gelindiğinde temel müzik yazı ve öğeleri konularına ağırlık verildiği görülmektedir. Beşinci sınıfta ayrıca Türk müziği usulleri üzerine yoğunlaşılmıştır. Rast ve Hüseyni makamları çeşitli örnekler ile açıklanıp, öğrencilerden bu makamlara ait eserleri söylemeleri beklenmiştir. Altıncı sınıfta da makamlar üzerine yoğunlaşılıp, Nikriz ve Nihavent makamları öğretilmiştir. Bir sonraki yıl yine iki makamın üzerinde durulduğu görülmektedir. Segah ve Hüzzam makamları çeşitli örnekler ile anlatılmış, öğrencilere söyletilecek eserler örnek olarak verilmiştir. Yurdumuzda müzikler konusu ile türkülerimizin yaşanmış öykülerine yer verilmiş ve geleneksel müziklerimiz çalışılmıştır. Türk müziğinin tarihsel süreci hakkında da bilgiler yer almaktadır. Sekizinci sınıfta Türk müziği uygulamaları aksak usullerin anlatımı ile başlar. Makamların türleri olan basit, bileşik ve göçürülmüş makamlar örneklendirilir. Kürdi ve Acemkürdi makamları detaylı olarak incelenir. Türk müziği biçimleri, türkü hikayeleri, mahalli sanatçılar ve müzik kültürümüze ses getirenler çeşitli örneklendirmeler ile açıklanmaktadır.

Lise evresine geçildiğinde öğrencilere MEB tarafından ilkokul ve ortaokul da dağıtılmakta olan ders kitabı dağıtılmamaktadır. Öğretmenler öğretim programı çerçevesinde derslerini yürütürler. Öğretim programı incelendiğinde lise evresindeki Türk müziği uygulamaları, makamlar, Türk müziği türleri, Türk müziği usulleri, Türk halk müziğinin yaşanmış öyküleri, Türk müziği tarihi, Türk halk müziği ve sanat müziğinin genel özellikleri, Türk halk müziği derleyicileri, Ozanlar ve aşıklar, Türk müziği biçimleri, çalgılar ve çok sesli Türk müzikleri konularıdır. Tüm bu konular sınıf seviyelerine göre derecelendirilmiş, her sinıf seviyesinde bir öncekinden daha detaylı olarak programda yer almıştır (MEB,2018).

\section{Araştırmanın Amacı ve Önemi}

Araştırmanın amacı; müzik öğretmenlerinin derslerinde uyguladıkları Türk müziği uygulamalarında çalgı eğitimi/öğretimine ilişkin görüşlerinin belirlenmesidir. $\mathrm{Bu}$ amaç doğrultusunda öğretim programı ile belirlenen derslerini yürüten müzik öğretmenlerinin Türk müziği uygulamaları ile ilgili yaşanan sorunların saptanması ve bu sorunlara çözüm önerilerinin getirilmesi amaçlanmıştır.

Araştırma sonuçları müzik öğretmenleri tarafindan uygulanmakta olan farklı öğretim tekniklerinin belirlenmesi, Türk müziği uygulamalarında çalg1 boyutunun incelenmesi ve Türk müziği öğretiminde çalgı kullanımı ile yapılacak diğer çalışmalara kaynak oluşturması bakımından önem arz etmektedir.

\section{Problem cümlesi}

Araştırmanın problem cümlesi, "genel müzik eğitiminde Türk müziği unsurlarının öğretilmesine yönelik çalgı boyutuna dair öğretmen görüşleri nasıldır?" olarak ifade edilmiştir. Belirlenen ana problem ışığında aşağıdaki alt problemlere cevap aranmıştır.

1. Öğretmenlerin genel müzik eğitiminde Türk müziği öğretimi ile ilgili görüşleri nelerdir?

2. Öğretmenlerin genel müzik eğitiminde çalgı boyutuna ilişkin görüşleri nelerdir?

3. Öğretmenlerin genel müzik eğitiminde Türk müziği unsurlarının öğretilmesine yönelik ve Türk müziği uygulamalarında çalgı boyutuna ilişkin görüşleri mesleki deneyimlerine göre farkl111k göstermektemidir?

4. Öğretmenlerin anket soruları haricinde çalışmaya sunduğu katkı ve görüşler nelerdir? 


\section{Yöntem}

\section{Araştırmanın Modeli}

$\mathrm{Bu}$ araştırma, müzik öğretmenlerinin derslerinde Türk müziği unsurlarının öğretilmesinde çalgı boyutuna ilişkin görüşlerini belirlemeye ilișkin tarama modelinde betimsel bir çalışmadır. Tarama modelleri, geçmişte veya günümüzde var olan bir durumu var olduğu şekli ile betimlemeye çalışan araştırmalardır. Araştırma konusu, kendi koşullarında ve olduğu gibi betimlenmeye çalışılır (Karasar,1998).

\section{Çalışma Grubu}

Araştırmanın çalışma grubunu, Türkiye'de resmi ve özel kurumlarda çalışmakta olan 1321 müzik öğretmeni oluşturmaktadır. Çalışmaya katılan öğretmenlere veriler sosyal platformlar aracılığı ile google forms uygulaması sayesinde ulaştırılmıştır. Öğretmenlerin meslek yaşantılarındaki deneyim süreleri Tablo l'de açıklanmıştır.

Tablo 1: Öğretmenlerin Deneyim Süreleri

\begin{tabular}{lcc}
\hline & f & \% \\
\hline $1-5$ & 300 & 22,7 \\
$6-10$ & 418 & 31,6 \\
$11-15$ & 191 & 14,5 \\
$16-20$ & 245 & 18,5 \\
$20-$ üzeri & 167 & 12,7 \\
\hline Toplam & $\mathbf{1 3 2 1}$ & $\mathbf{1 0 0}$ \\
\hline
\end{tabular}

\section{Veri Toplama Aracı}

Çalışmadaki veriler araştırmacı tarafından geliştirilen Türk müziği öğretiminin çalg1 boyutuna ilişkin öğretmen görüşlerini belirlemeyi amaçlayan anket formu ile sağlanmıştır. Anket formu geliştirilirken bilimsel çalışmalar taranmış, konu ile ilgili çalışmalar incelenmiştir. Anket formu üç ana başlık altında toplanmaktadır. Bunlardan ilki tek sorudan oluşan demografik sorudur. İkinci bölüm olarak toplam 15 sorudan oluşan ve 5'li likert tipi ifade tiplerinden oluşan sorular gelmektedir. Son bölüm ise öğretmenlerin çalışmaya ilişkin eklemek istedikleri görüşlerini yazabilecekleri açık uçlu bölüm yer almaktadır.

Anket sorularının oluşturulması için alan uzmanı olan (Gazi Üniversitesi Eğitim Fakültesi Müzik Eğitimi ABD Öğretim Üyeleri) 5 uzmanın görüşü alınmış olup, hazırlanan 19 soru içerisinden uzmanlar tarafından gereksiz görülen 4 soru çıkartılarak anket son halini almıştır. Anketin içerik geçerliliği için Lawshe tarafindan geliştirilen endeks puanlama sistemi kullanılmıştır. Uzmanlar tarafından tüm sorular için "madde hedefleneni ölçüyor", "madde konu ile ilgili ama gereksiz" ve "madde yapıyı ölçmez" ifadeleri işaretlenmiş sadece maddenin gerekli olduğu ibaresini işaretleyen uzmanların görüşleri endeks puanına eklenmiştir (Peach,2017). Lawshe içerik geçerlilik endeksi 0,867 olarak belirlenmiştir. 


\begin{tabular}{|c|c|c|c|c|c|c|}
\hline & Uzman 1 & Uzman 2 & Uzman 3 & Uzman 4 & Uzman 5 & CVR \\
\hline Soru 1 & $\mathrm{X}$ & $\mathrm{X}$ & $\mathrm{x}$ & $\mathrm{x}$ & & 0,6 \\
\hline Soru 2 & $\mathrm{x}$ & $\mathrm{x}$ & $\mathrm{x}$ & $\mathrm{x}$ & $\mathrm{x}$ & 1 \\
\hline Soru 3 & $\mathrm{x}$ & $\mathrm{x}$ & $\mathrm{x}$ & $\mathrm{x}$ & $\mathrm{x}$ & 1 \\
\hline Soru 4 & $\mathrm{x}$ & $\mathrm{x}$ & $\mathrm{x}$ & & $\mathrm{x}$ & 0,6 \\
\hline Soru 5 & $\mathrm{x}$ & $\mathrm{x}$ & $\mathrm{x}$ & $\mathrm{x}$ & $\mathrm{x}$ & 1 \\
\hline Soru 6 & & $\mathrm{x}$ & $\mathrm{x}$ & $\mathrm{x}$ & $\mathrm{x}$ & 0,6 \\
\hline Soru 7 & $\mathrm{x}$ & $\mathrm{x}$ & $\mathrm{x}$ & $\mathrm{x}$ & $\mathrm{x}$ & 1 \\
\hline Soru 8 & $\mathrm{x}$ & $\mathrm{x}$ & $\mathrm{x}$ & $\mathrm{x}$ & $\mathrm{x}$ & 1 \\
\hline Soru 9 & $\mathrm{x}$ & $\mathrm{x}$ & $\mathrm{x}$ & $\mathrm{x}$ & $\mathrm{x}$ & 1 \\
\hline Soru 10 & $\mathrm{x}$ & $\mathrm{x}$ & $\mathrm{x}$ & $\mathrm{x}$ & & 0,6 \\
\hline Soru 11 & $\mathrm{x}$ & $\mathrm{x}$ & $\mathrm{x}$ & $\mathrm{x}$ & $\mathrm{x}$ & 1 \\
\hline Soru 12 & $\mathrm{x}$ & $\mathrm{x}$ & $\mathrm{x}$ & $\mathrm{x}$ & & 0,6 \\
\hline Soru 13 & $\mathrm{x}$ & $\mathrm{x}$ & $\mathrm{x}$ & $\mathrm{x}$ & $\mathrm{x}$ & 1 \\
\hline Soru 14 & $\mathrm{x}$ & $\mathrm{x}$ & $\mathrm{x}$ & $\mathrm{x}$ & $\mathrm{x}$ & 1 \\
\hline Soru 15 & $\mathrm{x}$ & $\mathrm{x}$ & $\mathrm{x}$ & $\mathrm{x}$ & $\mathrm{x}$ & 1 \\
\hline CVI & & & & & & $\mathbf{0 , 8 6 7}$ \\
\hline
\end{tabular}

Ayrıca çalışmanın ölçme aracı olan anket formunun güvenirliği ile ilgili yapılan analizde ise, Crombach alpha katsayısı .74 olarak bulunmuştur. Maddelerin iç tutarlılığını ve birbirleri arasındaki homojen yapıyı açıklamak için kullanılan Crombach Alpha, $0.60<\mathrm{R} 2<0.80$ ise oldukça güvenilir olarak tanımlanır (Yıldız, Uzunsakal, 2018).

Kapsam geçerliliğinin sağlanmasının ardından ölçme aracının geçerlilik ve güvenirliliğini belirlemek için Kaiser-Meyer-Olkin KMO testi uygulanmıştır. Ölçme aracının KMO değeri .875 olarak belirlenmiştir. "Kaiser-MeyerOlkin değerinin yüksek olması, ölçekteki her bir değişkenin, diğer değişkenler tarafından mükemmel bir şekilde tahmin edilebileceği anlamına gelir. Değerlerin sıfır ya da sıfıra yakın çıkması durumunda, korelasyon dağılımında, bir dağınıklık olduğu için bu değerlere dayalı olarak yorum yapılamaz" (Çokluk ve diğerlerinden akt. Kaya,2013). Anketin yap1 geçerliliği için ayrıca faktör analizi yapılmıştır.

Tablo 3: Faktör Yükleri

\begin{tabular}{ccccccccccccccccc}
\hline Soru & 1 & 2 & 3 & 4 & 5 & 6 & 7 & 8 & 9 & 10 & 11 & 12 & 13 & 14 & 15 \\
\hline Faktör & .851 & .865 & .813 & .685 & .758 & .717 & .710 & .808 & .662 & .371 & .584 & .774 & .697 & .766 & .403
\end{tabular}

Tablo 3' de gösterildiği gibi öğretmenlerin derslerinde Türk müziği ile ilgili görüşlerini belirlemeyi amaçlayan maddelerin faktör yüklerinin .37 ile .85 arasında değiştiği görülmektedir. "Faktör yük değerinin .63 ve yükssek olması madde seçimi için iyi bir tercihtir. Ancak uygulamada az sayıda madde için bu sınır değer .30'a kadar indirilebilir" (Büyüköztürk, 2011).

Anket formunda yer alan ifadelerin aritmetik ortalamalar1; 4,21-5,00: Kesinlikle kat1liyorum, 3,41-4,20: Kat1liyorum, 2,61-3,41: Fikrim yok, 1,81-2,60: Kat1lmiyorum ve 1,00-1,80: Kesinlikle katılmıyorum olarak belirlenmiştir. Ayrıca anket formunda yer alan olumsuz ifadeler istatistik programına girilirken ters kodlanmış olup, veriler bu husus göz önünde bulundurularak anlamlandırılmaya çalışılmıştır.

\section{Verilerin Analizi}

Verilerin istatistiksel analizi için SPSS 22 programı kullanılmıştır. Elde edilen bulguların analizinde frekans (f), yüzde (\%), ortalama ( $\bar{x})$ ve standart sapma (ss) değerleri tablolar aracillğı ile 
yorumlanmıştır. Hazırlanan anket formu Türk müziği öğretimi boyutu ve çalg1 eğitimi boyutu olmak üzere 2 başlık altında toplanmaktadır. Belirlenen görüşlerin, öğretmenlerin mesleki deneyim süreleri ile olan anlam farklılıklarını ortay çıkartmak için tek yönlü varyans analizi (ANOVA) tekniği ile Welch ve Borwn-Forsythe testleri kullanılmıştır. Bu testlerde $\mathrm{p}<.05$ anlamlılık düzeyi esas alınmıştır.

\section{Bulgular}

Çalışmaya katılan öğretmenlerin Türk müziği öğretiminde çalgı boyutu ile ilgili görüşlerinin alındığı ölçme aracına verilen cevaplar açıklanmıştır. Araştırmanın ana faktörleri Türk müziği öğretimi boyutu ve çalg1 eğitimi boyutu tablolar aracıllğı ile her bir sorunun açıklanması sağlanmıştır.

\section{1. . Öğretmenlerin Genel Müzik Eğitiminde Türk Müziği Öğretimi İle İlgili Görüsşlerine Yönelik Bulgular}

Tablo 4: Türk Müziği Öğretimi Görüşleri

\begin{tabular}{|c|c|c|c|c|c|c|c|c|c|c|c|c|}
\hline \multirow[t]{2}{*}{ Sorular } & \multirow{2}{*}{\multicolumn{2}{|c|}{ 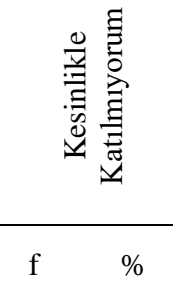 }} & \multirow{2}{*}{\multicolumn{2}{|c|}{ 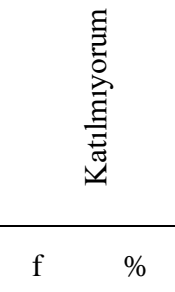 }} & \multirow{2}{*}{ 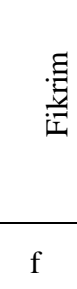 } & \multirow{2}{*}{$\begin{array}{l}\frac{y}{0} \\
\%\end{array}$} & \multirow{2}{*}{\multicolumn{2}{|c|}{ 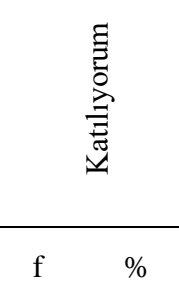 }} & \multirow{2}{*}{\multicolumn{2}{|c|}{ 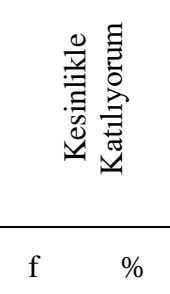 }} & \multirow[b]{2}{*}{$\overline{\mathrm{x}}$} & \multirow[b]{2}{*}{ SS } \\
\hline & & & & & & & & & & & & \\
\hline $\begin{array}{l}\text { Türk müziği öğretimi } \\
\text { alanında kendimi yeterli } \\
\text { bulurum. }\end{array}$ & 87 & 6,6 & 330 & 25 & 78 & 5,9 & 561 & 42,4 & 265 & 20,1 & 3,44 & 1,242 \\
\hline $\begin{array}{l}\text { Öğretim programında } \\
\text { içerik olarak Türk müziği } \\
\text { unsurları yeterlidir. }\end{array}$ & 130 & 9,8 & 638 & 48,3 & 150 & 11,4 & 315 & 23,8 & 88 & 6,7 & 2,69 & 1,134 \\
\hline $\begin{array}{l}\text { Türk müziği öğretiminde } \\
\text { öğrencilere koma sesi } \\
\text { anlatırken zorlanıyorum. }\end{array}$ & 76 & 5,8 & 275 & 20,8 & 140 & 10,6 & 559 & 42,3 & 271 & 20,5 & 3,50 & 1,192 \\
\hline $\begin{array}{l}\text { Makamsal ve tonal müzik } \\
\text { eğitimi bir arada } \\
\text { olmamalıdır. }\end{array}$ & 170 & 12,9 & 482 & 36,5 & 192 & 14,5 & 351 & 26,6 & 126 & 9,5 & 3,35 & 1,185 \\
\hline $\begin{array}{lr}\text { Türk müziği öğretimi ile } \\
\text { ilgili } & \text { akademik } \\
\text { çalışmaları } & \text { yeterli } \\
\text { buluyorum. } & \\
\end{array}$ & 207 & 15,7 & 582 & 44,1 & 283 & 21,4 & 200 & 15,1 & 49 & 3,7 & 2,47 & 1,043 \\
\hline $\begin{array}{l}\text { Türk/ Batı müziği } \\
\text { öğretimi ile ilgili ayrıca } \\
\text { hizmet içi eğitimler } \\
\text { düzenlenmelidir. }\end{array}$ & 31 & 2,3 & 96 & 7,3 & 85 & 6,4 & 616 & 46,6 & 493 & 37,3 & 4,09 & .960 \\
\hline $\begin{array}{l}\text { Türk müziği öğretimi için } \\
\text { yeni bir sistematik } \\
\text { yaklaşıma ihtiyaç vardır. }\end{array}$ & 38 & 2,9 & 92 & 7 & 153 & 11,6 & 639 & 48,4 & 399 & 30,2 & 3,95 & .976 \\
\hline $\begin{array}{l}\text { Öğrencilerin Türk müziği } \\
\text { konularına } \\
\text { yüksektir. }\end{array}$ & 223 & 16,9 & 537 & 40,7 & 151 & 11,4 & 343 & 26 & 67 & 5,1 & 2,61 & 1,182 \\
\hline
\end{tabular}

Tablo 4' de çalışmaya katılan öğretmenlerin derslerinde Türk müziği öğretimi ile ilgili görüşlerinin dağılımları incelendiğinde, en yüksek ortalama ( $\bar{x}: 4.09$, ss: .960) Türk/Batı müziği 
öğretimi ile ilgili ayrıca hizmet içi eğitimler düzenlenmelidir iken, en düşük ortalama ( $\mathrm{x}: 2.61$, ss: 1.182) öğrencilerin Türk müziği konularına ilgileri düzeyleri olarak belirlenmiştir.

Öğretmenlerin büyük bir çoğunluğu Türk müziği öğretiminde kendini yeterli bulmaktadır (f:826 \%62,5 $\bar{x}: 3,44)$. Öğretim programında içerik olarak Türk müziği unsurlarının yeterliliği ile ilgili olan soruya, öğretmenlerin büyük bir çoğunluğu öğretim programının yetersiz olduğu konusunda görüş bildirmişlerdir (f:768 \%58,1 $\bar{x}: 2,69$ ). Türk müziği öğretiminde öğrencilere koma sesi anlatırken zorlanıyorum sorusuna ilişkin bulgular büyük oranda zorlanıldığını göstermektedir (f:830 \%62,8 $\bar{x}: 3,50$ ). Makamsal ve tonal müzik eğitimi bir arada olamamalıdır sorusuna verilen cevaplarda bu görüşe katılanların oranı \%36,1 iken, katılmayanların oranı ise \%49,4 olarak belirlenmiştir. Öğretmenlerin yarısına yakını her iki müzik türünün aynı anda öğretilmesinde bir sakınca olmadığını, diğer yarısının da bu iki türün ayrılması gerektiğini ve fikirlerinin olmadığını düşünmektedir ( $\mathrm{x}: 3 \cdot 35)$.

Türk müziği ile ilgili akademik çalışmaların yeterliliği ile ilgili soruya verilen cevapların büyük bir oranı $(\% 59.8)$ çalışmaları yetersiz bulduklarını beyan etmişlerdir $(\overline{\mathrm{x}}: 2,47)$. Çalışmaya katılan öğretmenlerin verdikleri cevap ortalamalarının en düşük olduğu, Türk/Batı müziği ile ilgili ayrıca hizmet içi eğitimler düzenlenmelidir sorusu büyük çoğunlukla \%84 gerekli görülmüştür $(\overline{\mathrm{x}}: 4,09)$. Türk müziği öğretimi için yeni bir sistematik yaklaşıma ihtiyaç duyanların oranı $\mathrm{f}: 1038$, \% 78.5 dir. Öğretmenlerin tamamına yakını Türk müziği öğretiminde yeni bir öğretim modelinin tasarlanması gerektiğini düşünmektedir ( $\mathrm{x}: 3,95)$. Derslerinde öğrencilerin Türk müziği konularına ilgilerinin düşük olduğunu belirten öğretmenlerin oranı \% 57.5 dir. Çalışmaya katılan öğretmenlerin yarısından fazlası öğrencilerinin Türk müziği konularına ilgi düzeylerinin düşük olduğunu savunmaktadır ( $\bar{x}: 2,61)$.

Tablo 4 de öğretmenlerin Türk müziği öğretimi ile ilgili sorulara verdikleri cevapların istatiksel açıklamalarına yer verilmiştir. 8 sorudan oluşan bu bölüme ait toplam ortalama değer $\overline{\mathrm{x}}: 3,26$ olarak belirlenmiştir. Standart sapma ise ss: 1,114 olarak hesaplanmıştır. Çalışmaya katılan öğretmenlerin Türk müziği öğretimi ile ilgili verdikleri cevaplara genel bir ifade ile $(\overline{\mathrm{x}}: 3,26)$ katıldıkları söylenebilir. 


\section{2. . Öğretmenlerin Genel Müzik Eğitiminde Çalgı Boyutuna İlişkin Görüşlerine Yönelik Bulgular}

Tablo 5: Çalg1 Boyutu ile İlgili Görüşler

\begin{tabular}{|c|c|c|c|c|c|c|c|c|c|c|c|c|}
\hline \multirow[t]{2}{*}{ Sorular } & \multicolumn{2}{|c|}{ 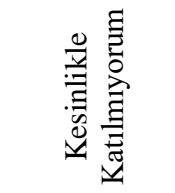 } & \multicolumn{2}{|c|}{ 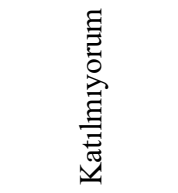 } & 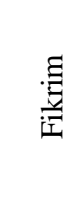 & $\frac{y}{\partial}$ & \multicolumn{2}{|c|}{ 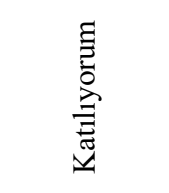 } & \multicolumn{2}{|c|}{ 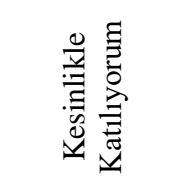 } & \multirow[b]{2}{*}{$\overline{\mathrm{x}}$} & \multirow[b]{2}{*}{ ss } \\
\hline & $\mathrm{f}$ & $\%$ & $\mathrm{f}$ & $\%$ & $\mathrm{f}$ & $\%$ & $\mathrm{f}$ & $\%$ & $\mathrm{f}$ & $\%$ & & \\
\hline $\begin{array}{l}\text { Derslerimde Türk müziği } \\
\text { çalgısı kullanırım. }\end{array}$ & 163 & 12,3 & 462 & 35 & 61 & 4,6 & 392 & 29,7 & 243 & 18,4 & 3,06 & 1,368 \\
\hline $\begin{array}{l}\text { Müzik derslerinde Blok } \\
\text { flüt okul çalgisı olarak } \\
\text { yeterlidir. }\end{array}$ & 441 & 33,4 & 622 & 47,2 & 27 & 2 & 126 & 9,5 & 105 & 7,9 & 2,11 & 1,199 \\
\hline $\begin{array}{l}\text { Öğrencilere batı ve Türk } \\
\text { müziği çaldırabileceğim } \\
\text { ortak bir okul çalgıs } \\
\text { olmasını isterim. }\end{array}$ & 57 & 4,3 & 121 & 9,2 & 140 & 10,6 & 595 & 45 & 408 & 30,9 & 3,88 & 1,07 \\
\hline $\begin{array}{l}\text { Çalg1 öğretimi müzik } \\
\text { eğitiminde önemli bir } \\
\text { boyuttur. }\end{array}$ & 43 & 3,3 & 51 & 3,8 & 39 & 3 & 516 & 39,1 & 672 & 50,8 & 4,30 & .945 \\
\hline $\begin{array}{lr}\text { Öğrencilerin } & \text { geleneksel } \\
\text { müziklerimizi } & \text { çalarak } \\
\text { öğrenmesi } & \text { kalıcılığ } \\
\text { arttırır. } & \\
\end{array}$ & 30 & 2,3 & 115 & 8,7 & 68 & 5,1 & 645 & 48,8 & 463 & 35,1 & 4,05 & .975 \\
\hline $\begin{array}{l}\text { Türk müziği öğretimi için } \\
\text { mevcut okul çalgıları } \\
\text { yetersizdir. }\end{array}$ & 61 & 4,6 & 66 & 5 & 56 & 4,2 & 653 & 49,5 & 485 & 36,7 & 4,08 & 1,009 \\
\hline $\begin{array}{l}\text { Derslerimde öğrencilere } \\
\text { okul çalgısı çaldırırım. }\end{array}$ & 73 & 5,5 & 165 & 12,5 & 65 & 4,9 & 736 & 55,7 & 282 & 21,4 & 3,74 & 1,094 \\
\hline
\end{tabular}

Tablo 5 de çalışmaya katılan müzik öğretmenlerinin derslerinde Türk müziği uygulamaları ile ilgili çalgı boyutuna ilişkin görüşleri açıklanmıştır. Bu bilgiler ışığında öğretmenlerin görüşlerinin en yüksek ortalama ile ( $\bar{x}: 4,30$ ss: .945) çalgı öğretimi müzik eğitiminde önemli bir boyuttur sorusunda, en düşük ortalama ise $(\overline{\mathrm{x}}$ : 2,11 ss: 1,199$)$ müzik derslerinde blok flüt okul çalgısı olarak yeterlidir sorusu olarak belirlenmiştir.

Derslerinde Türk müziği çalgısı kullanan öğretmenlerin oran1 f:635 \%48,1 iken, kullanmayanların oranı ise f:625 \%47,3 olarak belirlenmiştir ( $\bar{x}: 3,06)$. Öğretmenlerin yaklaşık olarak yarısı derslerinde Türk müziği çalgısı kullanmamaktadır. Müzik derslerinde blok flütün okul çalgısı olarak yeterli olmadığını belirten öğretmenlerin oranı f: $1063 \% 80,6$ x :2,11' dir. Bu sonuçlara göre çalışmaya katılan öğretmenlerin büyük bir çoğunluğu, blok flütün okul çalgısı olarak yetersiz olduğunu savunmaktadır. Öğrencilere Batı ve Türk müziğini çaldırabileceği ortak bir çalgının olmasını isteyen öğretmenlerin oranı f: $924 \% 75,9$ x:3,88' dir. Her iki müziğinde çalınabileceği ortak bir çalgıyı öğretmenlerin büyük bir çoğunluğu istemektedir.

Çalışmaya katılan öğretmenlerin neredeyse tamamı f:1188 \%89,9' u, çalgı öğretiminin müzik eğitiminde önemli bir boyut olduğunu düşünmektedir. Bu soru ile ilgili ortalama $\bar{x}: 4,30$ olarak belirlenmiştir. Öğrencilerin geleneksel müziklerimizi çalarak öğrenmesinin kalıcılığı arttıracağ1 görüşünü savunan öğretmenlerin oranı f: 1108 \% 83,9 x̃: 4,05' dir. Öğretmenlerin büyük bir çoğunluğu geleneksel müziklerimizin çalarak öğrenilmesinde kalıcı bir etki bırakacağı görüşünü belirtmişlerdir. Türk müziği öğretimi için mevcut okul çalgılarının yeterliliği ile ilgili soruya, 
öğretmenlerin f: $127 \%$ 9,6' s1 yeterli cevabını verirken, f: $1138 \%$ 86,2' si yetersiz olduğu görüşünü bildirmiştir. Öğretmenlerin büyük bir çoğunluğunun mevcut okul çalgılarının Türk müziği öğretimi için yeterli olmadığ 1 görüşünde oldukları belirlenmiştir $(\overline{\mathrm{x}}: 4,08)$. Müzik derslerinde öğrencilerine okul çalgısı çaldıran öğretmenlerin oranı f: $1018 \% 77,1$ iken, çaldırmayan öğretmenlerin oranı f:238 \%18'dir. $\mathrm{Bu}$ soruda da verilen cevaplar doğrultusunda, öğretmenlerin büyük bir çoğunluğunun müzik derslerinde okul çalgısı kullandıkları sonucuna varılmıştır.

Tablo 5'de öğretmenlerin derslerinde çalg1 eğitimi ile ilgili görüşlerinin istatiksel açıklamalarına yer verilmiştir. 7 sorudan oluşan bu bölüme ait toplam ortalama değer $\overline{\mathrm{x}}: 3,60$ olarak, standart sapma ise ss: 1,094 olarak belirlenmiştir.Çalışmaya katılan toplam n:1321 öğretmenin çalg1 eğitimi ile ilgili verdikleri cevaplara genel bir ifade ile (x:3,60) katıldıkları sonucuna var1labilir.

Türk müziği öğretimi ile ilgili elde edilen bulguların sonucunda, öğretmenlerin Türk müziği öğretimi ve çalgi eğitimi ile ilgili görüşlerinin, mesleki deneyim süreleri ile ilgili anlamlı bir farklılığın olup olmadığ 1 test edilmiştir.

\section{3. Öğretmenlerin Verdiği Cevapların Mesleki Deneyimlerine İlişkin Geçerlik ve Güvenirlik Durumuna Yönelik Bulgular}

Tablo 6: Türk Müziği Öğretimi ve Çalgı Eğitiminin Deneyim ile İlişsisi

\begin{tabular}{lccccc}
\hline \multicolumn{5}{c}{ Homogeneity of Variances } & \multicolumn{3}{c}{ ANOVA } \\
\hline & Levene St. & Sig. & Mean Sq. & F & Sig \\
\hline Türk Müziği & 49.654 & .000 & 16.170 & 152.084 & .000 \\
Öğretimi & 22.055 & .000 & 61.038 & 379.214 & .000 \\
Çalg1 Eğitimi & & & & & \\
\hline
\end{tabular}

Çalışmaya katılan öğretmenlerden elde edilen bilgiler doğrultusunda, öğretmenlerin derslerinde kullandıkları Türk müziği öğretimi ile ilgili bilgilerin, çalgı eğitimi hakkında elde edilen bilgiler ile öğretmenlerin mesleki deneyimleri ile aralarında fark olup olmadığını belirlemek için ANOVA testi uygulanmıştır. Tablo 6' da gösterildiği üzere, testin ilk aşaması olan Levene homojenlik sonuçlarına göre $\mathrm{p}<0.05$, gruplar arasında homojen bir dağılım olmadığ 1 gözlemlenmektedir.

Gruplar arasında homojenliğin sağlanamadığı durumlarda Brown-Forsythe F ve Welch's testlerine başvurulmuştur. “Eğer Levene's testten elde ettiğimiz p değeri 0.05 'ten küçük ise bu hipotezi reddeder ve varyans homojenliği varsayımının sağlanmadığını söyleriz. Bu durumda ANOVA tablosunda verilen $\mathrm{F}$ ve $\mathrm{p}$ değerlerini kullanamayı. Bunun yerine SPSS'te sunulan Brown-Forsythe F (1974), ve Welch's F (1951) istatistikleri yoluyla elde edilen F değeri ve buna bağlı p değeri kullanılır'(Şen,2016).

Tablo 7: Welch, Brown-Forsythe Testi

\begin{tabular}{ccccc}
\hline & \multicolumn{2}{c}{ Welch } & \multicolumn{2}{c}{ Brown - Forsythe } \\
\hline & Statistic & Sig. & Statistic & Sig. \\
\hline $\begin{array}{c}\text { Türk müziği } \\
\text { öğretimi }\end{array}$ & 162.226 & .000 & 579.993 & .000 \\
\hline Çalg1 öğretimi & 212.024 & .000 & 316.106 & .000 \\
\hline
\end{tabular}

Anova testinin ön koşulu olan homojenlik sağlanamadığ için uygulanan Welch ve BorwnForsythe testlerinden elde edilen sonuçlarda $\mathrm{p}$ değeri 0.05 den küçük olarak bulunmuştur. $\mathrm{Bu}$ sonuçlar doğrultusunda, çalışmaya katılan öğretmenlerin Türk müziği öğretimi ve çalgı öğretimi boyutunda elde edilen sonuçlarının, öğretmenlerin mesleki deneyimleri ile ilgili bir farklılık bulunmadığı sonucuna varılabilir. 


\section{4. Öğretmenlerin Anket Soruları Haricinde Çalışmaya Sunduğu Katkı ve Görüşlere Yönelik Bulgular}

Anket formunun son bölümünde, öğretmenlerin çalışma ile ilgili eklemek istedikleri görüşlerini belirtmek için açık uçlu bir bölüm bulunmaktadır. Bu bölümde ekleme yapmak isteyen öğretmenlerin görüşleri alınmış olup, çalışmaya katkı sunduğu düşünülen görüşler öğretmenlere Ö1,Ö2,Ö3 gibi rumuzlar verilerek aktarılmıştır.10 öğretmenin görüşleri yorumlanmaya çalış1larak çalışmaya aktarılmıştır.

Ö1 konu ile ilgili, "Öğrencilerin istek ve beklenti düzeylerini ölçerek müzik beğenilerini bireysel değerlendirmek lazım olduğunu düşünüyorum. Bu nedenle Batı ve Türk müziği eğitimini genelde düşünerek basit bir şekilde değerlendirilmesi, temel bilgiler akabinde isteyen öğrenci profiline seçme şansı bırakılarak ikinci bir müzik eğitimi sunulması gerektiğini düşünüyorum" şeklinde görüş bildirmiştir. Ö1' in görüşüne göre, temel genel müzik eğitiminin yanında, istekli ve yetenekli öğrenciler ile daha derinlemesine bir müzik eğitimi programı tasarlanabilir. Bu durumda Türk müziği öğretimi ile ilgili detaylı bilgiler öğrenciye aktarılabilir ve etkili bir müzik eğitimi gerçekleştirilebilir.

Bir diğer öğretmen Ö2 konu ile ilgili, "Yeni müzik müfredatımızda çalg1 eğitiminin olmaması kalıcı öğrenmeyi zorlaştırmaktadır. Ayrıca Türk müziği konularında makamsal etki teorik olarak daha basite indirgenerek repertuar ağılıklı olmalıdır" şeklinde görüş bildirmiştir. Görüldüğü gibi çalgı öğrenme alanının öğretim programından kaldırılması öğretmenler tarafından olumsuz olarak değerlendirilmektedir. Ö3 ise, "Çalg1 öğrenme alanları ortaöğretim alanından kaldırıldı fakat gerekçe şöyle; TTKB (Talim ve terbiye kurulu başkanlığı) öğretim programları haricinde çalgı sınıfı modülü oluşturma çalışmaları yapıyordu. Henüz neticelenmedi. Umarım hayata geçirilebilir. Bu sayede Türk Batı ayırımı yapılmaksızın çalgı sınıfları oluşturulabilir" görüşünü belirtmiş̧ir. Ttkb tarafindan hazırlanacak olan çalgı öğrenme modülleri ile daha etkili ve sistematik bir çalgı öğrenme boyutunun gerçekleşebileceği düşünülmektedir.

Ö4 ise, "Ders kitapları öğrenci düzeyinde şarkılar içermiyor. Kaynak kitap çok az. Eski kitaplar daha başarılıydı. Melodikayı öğrenciler daha çok seviyor". Bu görüşe göre ders kitaplarında yer verilen eserlerin öğrenci düzeylerinin çok üstünde olduğu söylenmektedir. Öğretmenin öğretimi geçekleştirmek için ders kitaplarının dışında başka kaynaklara yöneldiği ve bu kaynaklardan da tam olarak yararlanamadığı söylenebilir. Okul çalgısı olarak da öğrenciler tarafından melodikanın daha çok tercih edildiği düşünülmektedir. Ö5'in görüşü ise, "Sadece çalg1 çaldırarak değil, öğretilen her makam ile ilgili örnek nitelikli eser seslendirmelerini sağlayarak da öğrencilerin bilgileri daha kalıcı hale getirilebilir. Okul yıllarında çaldıkları çalgıyı, seslendirdikleri eseri belki unutabilirler ama şarkılar daha akılda kalıcı olabilir" şeklindedir. Bu görüşten ise şu sonuçlar çıkartılabilir. Öğrenciye çalgı çaldırmak yerine öğrettiğimiz makamla ilgili öğrencinin seviyesine uygun nitelikli eserler ile kalıcı bir öğrenme sağlanabilir. Bu durumunda yine öğretim programında değişiklik yapılarak mümkün olacağı düşünülmektedir.

Çalışmaya katılan mesleki deneyimi 20 yılın üstünde bulunan Ö6, "Her öğrencimin iyi ya da kötü bir enstrüman çalması için çabalıyorum. Türk müziğinde bilgi sahibi olmayan çok meslektaşım olduğunu düşünüyorum. Bu alanda bilgi açığımızı kapatmak için çalışmalar yapılmalıdır. İlk başta eğitim dönemi içerisinde bu açı̆̆ 1 kapatmak için eğitim fakültesi müzik bölümü öğrencilerine eğitim verilmesi lazımdır. Farklı müzik bölümünde mezun olan arkadaşlarımın çaldıkları enstrüman ve dersler bile birbiri ile uyuşmamaktadır. Bu da gösteriyor ki bu açığı kapatmamız gerek. Birde şuna değinmek istiyorum, öğretmen olup da Türkiye'nin her yerine atanan arkadaşlarımız nasıl Türk müziği eğitimi ve çalgı eğitimi verebilir. Bence şu bir gerçektir ki Türk müziği eğitiminin açı̆̆ı o ya da bu şekilde çözüme kavuşmalıdır. Bu gibi anketlerin yapılması bile açığın kapatılması için bir başlangıçtır" şeklinde görüş bildirmiştir. 
Yukarıdaki görüşlere göre, çalgı eğitimi öğretim programından kaldırılmasına rağmen öğretmenler tarafindan gerçekleştirilmeye devam etmektedir. Öğretmenlerin Türk müziği öğretimi ile ilgili donanımlarında eksiklikler olduğu ve bu eksikliklerin öğretmenler tarafından da farkında olunduğu söylenebilir. Türk müziği öğretimi ile ilgili hizmet içi eğitimlerin yapılmasının, öğretmenler için de olumlu karşılanacağı düşünülmektedir.

Ö7 "Ders saatlerinin yetersizliği tüm konuların üzerindedir. Tüm araştırmaların sebebi ve sonucunu birebir etkileyebilecek en önemli konu ders saatlerinin yetersizliğidir" şeklinde görüş bildirmiştir. Bu görüşe göre ise, ortaokullarda haftada 1 saat, liselerde ise seçmeli olarak 2 saat olarak yürütülen müzik derslerinin, özellikle ortaokullarda ders saatinin az olması nedeni ile çeşitli zorluklara neden olduğu söylenebilir. Öğrencilere haftada bir ders saatinde gerekli kazanımların aktarılmasında eksiklikler olabileceği düşünülmektedir. Ö8 ise, "Okul kitaplarında daha çok Türk halk müziği söylemek ve çalmak istiyoruz" demiştir. Okul kitapları öğretim programının doğrultusunda hazırlanmaktadır. $\mathrm{Bu}$ programlar göz önüne alındığında tüm müziklerin örneklendirmeleri yapılmıştır. Öğrencilerin Türk müziği konuları içerisinde Türk halk müziğine olan yatkınlıkları düşünüldüğünde, halk müziği örneklendirmelerinin sayı olarak arttırılmasının, öğrencilerin Türk müziği öğrenimi ile ilgili algılarında anlamlı bir fark yaratacağı düşünülmektedir.

Ö9, "Müzik derslerine ilkokul 1.sınıftan itibaren branş öğretmeni girmelidir. Ders saati ortaöğretim 12.sınıfın sonuna kadar haftada en az 2 ders saati olarak düzenlenmelidir. Müzik dersi 7.sınıftan itibaren seçmeli olmalıdır. Okul içi müzik kurslarında kursun açılabilmesi için zorunlu tutulan en az 10 öğrenci kuralı iptal edilmelidir" şeklinde görüş bildirmiştir. $\mathrm{Bu}$ görüş doğrultusunda, ders saatlerinin yetersizliği ve ilkokullarda derslere müzik öğretmenlerinin girmesi gerekliliği vurgulanmıştır. Eğitim fakültelerinin temel eğitim bölümlerinde bir dönem müzik eğitimi alan sınıf öğretmenleri müzik öğretimi ile ilgili yeterli donanıma sahip olmadan mezun olmaktadırlar. "Sınıf öğretmenleri öğrenim yıllarında müzik dersini almakla birlikte müzik öğretimi konusunda kendilerini yeterli görmemekte ve müzikle öğretim yöntem ve tekniklerine ilişkin hizmet içi eğitimi gerekli görmektedirler (Kocabaş,2000). Bu durum öğrencinin eğitim hayatının ilk 4 yılında sağlıksız bir müzik eğitimi almasına neden olmaktadır. Temel eğitim bölümlerinde müzik eğitimi alan sınıf öğretmenlerinin aldıkları eğitimin nitelik ve nicelik olarak yeniden gözden geçirilmesinin, genel müzik eğitimine olumlu katkılarının olacağ 1 düşünülmektedir. İlgi düzeylerine göre, öğrencilerin belirli genel müzik eğitimini tamamladıktan sonra seçmeli olarak ders saatlerinin arttırılarak müzik eğitimine devam etmelerinin olumlu yansımalarının olacağı tahmin edilebilir.

Çalışmaya katılan 35 yıllık deneyime sahip Ö10, "Müzik öğretmenliğim boyunca Türk müziği öğretecek öğrenci bulmakta zorlandım. Hâlbuki Türk müziği ile ilgili seminer ve kurslara katılmak için iki yaz tatilimi heba ettim bu konuda kendimi geliştirdim ama aktaracak öğrenci profili yok. Öğrenci Kore müziği vb yabancı müzik dinliyor" şeklinde görüş bildirmiştir. $\mathrm{Bu}$ görüşler 1şığında, öğrencilerin Türk müziği konularına ilgi düzeylerinin düşük olduğu söylenebilir. Öğretmenlerin özelikle Türk müziği ile ilgili bilgilerinin yetersizliği ve bu durumu ortadan kaldırmak için kendi imkânları ile seminer, çalıştay gibi etkinliklere katıldıkları söylenebilir. Öğrencilerin Türk müziğine olan ilgisizliklerinin giderilmesi için acilen yeni sistematik bir programa ihtiyaç duyulduğu gözlenmektedir.

\section{Sonuç ve Tartışma}

Müzik dersi öğretim programında Türk müziği öğretimi ile ilgili kazanımlara yer verilmiştir. Bu kazanımlar ilkokul evresinde 12, ortaokul evresinde 32 ve lise evresinde ise 36 kazanımdır (MEB,2018). Öğretmenler Türk müziği ile ilgili bu kazanımları öğrencilerine aktarırken çeşitli materyallerden yardım alırlar. Bunların başında Türk müziği ses sisteminin en önemli unsuru olan koma sesi oluşturabilmek için bir Türk müziği çalgısı gelmektedir. Mevcut okul çalgıları içerisinde yer alan çalgılar tonal müzik ses sistemi için tasarlandıklarından, öğrencilerin kendileri tarafindan çalınarak Türk müziği oluşturabileceği bir okul çalgısı yoktur. 
Bu durumda öğretmenler kendi çaldıkları bir Türk müziği çalgısı ya da dinleme yöntemi ile öğrencilerine öğrenim gerekleştirirler. Eğitim fakültelerinin güzel sanatlar eğitimi bölümlerinden mezun olan kişiler, öğrenim gördükleri okullarda okul çalgıları dersleri aldıkları için bir Türk müziği çalgısı (bağlama) çalma becerisine sahiptir (YÖK,2018). Eğitim fakültelerinin güzel sanatlar eğitimi bölümlerinden mezun olan öğretmenlerin dışında, güzel sanatlar fakülteleri ile devlet konservatuarlarından mezun olan bireyler de formasyon alarak öğretmen olabilmektedirler. Bu bölümlere ait ders programları (Akdeniz Ünv, Erciyes Ünv, Dokuz Eylül Ünv, Atatürk Ünv. müzik bölümleri ders programları, 2020) incelendiğinde de görüldügü üzere, Türk müziği ile ilgili teorik derslerin olması yanında, Türk müziği öğretimini gerçekleştirebilecekleri çalgi öğretimi ile ilgili herhangi bir dersin olmadığ 1 gözlenmiştir. Kendi kişisel çalışmaları olan bireyler mevcut olabilir. Ancak program çıktılarında böyle bir durum söz konusu değildir. Derslerinde bir Türk müziği çalgısı kullanma durumlarına bakıldığında da, öğretmenlerin \%35,3'ünün çalg1 kullanmadığı belirlenmiştir. Bu durumun Türk müziği öğretimi ile ilgili bir eksiklik olduğu düşünülmektedir. Türk müziği çalmaya elverişli bir okul çalgısı olmadığı düşünüldüğünde, öğretmen tarafından bu ezgilerin öğrencilere dinletilememesi, Türk müziği öğretiminde bir problem teşkil ettiği söylenebilir.

Çalışmaya katılan 1321 öğretmenden alınan cevaplar doğrultusunda, öğretmenlerden büyük çoğunluğu $(\% 62,6$ x: 3,44) Türk müziği öğretimi ile ilgili kendilerini yeterli bulmaktadırlar. Öğretim programında içerik olarak Türk müziği unsurlarının yetersiz olduğunu düşünen öğretmenlerin oranı \%58,1'dir. Öğretim programları sarmal bir şekilde okul öncesi dönemden başlayıp, ilköğretim ve orta öğretim seviyelerinde birbirini tamamlayacak şekilde amaçlar doğrultusunda öğrenimi gerçekleştirir (MEB,2018). Bu oranla, öğretim programındaki Türk müziği alanlarının yeniden gözden geçirilip değerlendirilmesi gerektiği sonucuna varılabilir.

Ülkemizde en yaygın olarak kullanılan okul çalgısı blok flüttür. Blok flüt ekonomik olması, taşınabilirliğindeki kolaylık ve ses çıkartmadaki kolaylığı gibi etkenler dolayısı ile tercih sebebi olmaktadır. Blok flütün sağladığı kolaylıkların yanında, Türk müziği icrasındaki problemleri, akort problemi gibi sorunları da mevcuttur. Müzik derslerini ilkokul evresinde yürütmekte olan sınıf öğretmenlerine de blok flüt ile eğitim verilmektedir. Eğitim fakültelerinin temel eğitim bölümlerinde öğrenim gören öğrencilere çalg1 öğretimi büyük oranda blok flüt ile gerçekleşmektedir. Blok flüt, öğrenilmesinin kolaylığı, ekonomik olması, taşınma kolaylı̆̆ 1 ve repertuarının genişliği bakımından tercih edilmektedir (Kurtaslan \& Koca, 2013). Çalışmaya katılan öğretmenlerin büyük bir çoğunluğu $(\% 80,5$ x̃: 2,11$)$ blok flütü sadece Türk müziği öğretimi ile ilgili değil, genel olarak yetersiz bulmaktadır. Müzik derslerinin ilkokul evresinde yürütmekte olan sınıf öğretmenlerinin de müzik yeterliliklerinin bu dersi yönetmekte yetersiz olduğu düşünülmektedir. Kocabaş (2000) sınıf öğretmenlerinin müzik derslerindeki uygulamaları ile ilgili, sınıf öğretmenlerinin, bilişsel, duyuşsal ve devinişsel bakımlardan üst stratejiler gerektiren müzik dersinin öğrencilerin gelişimine yeterli katkıda bulunmadığg sonucuna varmıştır.

Elde edilen sonuçlardan bir tanesi de öğretmenlerin Türk müziği ile tonal müziği aynı anda çaldırabilecekleri bir okul çalgısını isteme durumlarıdır. Çalışmaya katılan öğretmenlerin \% $75,9^{\prime} \mathrm{u}$ $(\bar{x}: 3,88)$ böyle bir okul çalgısını istemektedirler. Karataş ve Kılıç (2017) Ortaöğretim düzeyi müzik derslerinde kullanılan okul çalgıları ve bu çalgıların öğretiminde karşılaşılan sorunların incelenmesi isimli çalışmalarında öğretmenlere kullandıkları okul çalgıları ile ilgili sorular yöneltmişlerdir. Öğretmen 23 "Hiçbirini çaldırmak istemiyorum. Blok flüt aldırmak istemiyorum. Blok flüt çaldırmamamdaki en önemli etkenlerden biride şu çocukların günlük yaşantılarındaki, evlerindeki, beyinlerindeki müzikle, flütle çalınan şarkılar veya batı müziğindeki tampere sistemin bizim müziğimizi ifade etmede yetersiz kalmasıdır" şeklinde yanıtlamıştır. Öğrencilerin özellikle makamsal eserleri çalmaya çalıştıklarında karşılaşılan durumdan rahatsız olan öğretmenler bulunmaktadir. 
Diğer bir önemli sonuç ise, öğretmenlerin okul çalgılan ile bir çok sorun yaşasalar da çalg1 öğretiminin müzik eğitiminde önemli bir boyut olduğunu düşünmeleridir. Öğretmenlerden \%90'ı çalg1 öğretiminin önemini vurgulamıştır. Özen (2004) çalışmasında çalgı eğitiminin bilişsel, duyuşsal ve devinişsel faydalarından bahsetmektedir. Çalg1 eğitiminde terimlerin öğrenilmesi ve gerekli tekniklerin kavranması bilişsel, çalgının sevilmesi, çalmaya ilişkin disiplinli çalışmaya yönelik bir tutum geliştirilmesi ve çalg1 çalmaya yaşantıda yer verilmesi duyuşsal alan, çalgı çalmada iki elin eş güdümünün sağlanması ise devinişsel alan olarak açıklanmıştır. Görüldüğü gibi çalgı çalmak öğrencinin bilişsel, duyuşsal ve devinişsel alanlarda gelişimini destekler (Özen,2004). 2018 yılında yapılan değişiklik ile müzik dersi öğretim programından çalg1 öğrenme alanı çıkartılmıştır. Elde edilen bu veriler doğrultusunda çalgı öğretiminin tekrardan öğretim programı içerisine alınması gerektiği sonucuna varılabilir.

Öğrenme öğretme sürecinde yaparak yaşayarak öğrenme şüphesiz ki önemli bir etkendir. Öğretmenlerin \%83,3ü ( $\bar{x}$ : 4,05) öğrencilerin geleneksel müziklerimiz çalarak öğrenmesinin kalıcılığı arttıracağı kanısındadır. Bu sonuçtan da anlaşılacağı üzere geleneksel müziklerimizin çalınabileceği okul çalgısına ihtiyaç duyulmaktadır. Türk müziğini tonal müzikten ayıran en önemli unsur, müziğimizi diğer müziklerden ayıran ses sistemidir. Bu ses sistemi içerisinde koma sesler olarak adlandırılan farklı yapıları barındırır. Geleneksel müzikler micro ses sistemine dâhil olup; yatay anlamda nağme müziği eksenine dayanır. Klasik Türk Müziği eşit olmayan 24 perdeden (Arel-Ezgi-Uzdilek'e göre), Türk Halk Müziği ise yine birbirine eşit olmayan 17 perdeden oluşmuştur (Albuz,2011). Tonal ses sisteminde bir tam ses iki eşit parçaya ayrılmışken, Türk müziğinde bir tam ses dokuz eşit parçaya bölünmüştür. Çalışmaya katılan öğretmenlere bu koma seslerin öğretiminde karşılaşılan zorluklar hakkında soru sorulmuştur. \%62,8 oranında toplam 830 öğretmen, öğrencilere koma sesi anlatırken zorlandığını beyan etmiştir.

Türk müziği öğretimi için mevcut okul çalgılarının durumu ile ilgili sorulan soruya öğretmenlerin büyük bir bölümü yetersiz yanıtını vermiştir. $\% 86,1$ oranında $(\bar{x}: 4,08)$ öğretmen mevcut okul çalgıları ile Türk müziği öğretiminin gerçekleştirilemeyeceği görüşünü belirtmiştir. $\mathrm{Bu}$ sonuçlar doğrultusunda okul çalgısı bağlamında yeni çözüm yolları bulunmalıdır. Türk müziğinin makamsal yapısı ve ses sistemindeki doğal değişiklikler ile tonal müziğin sistemi anlam bakımından farklılıklar içermektedirler. Bu farklılıklar öğrenme güçlüklerini de beraberinde getirebilir. Öğrenciler makamsal yapı ile tonal yapı arasındaki bağları kurmakta zorlanabilirler. $\mathrm{Bu}$ bağlamda öğretmenlere makamsal müzik ile tonal müzik öğretiminin bir arada olma durumları ile ilgili soru yöneltilmiş, \%12,9 kesinlikle katılmadığını, \%36,5 katılmadığını, \%14,5 fikrinin olmadığını, \%26,6 katıldığını ve \%9,5 kesinlikle katıldığını belirtmiştir. Sonuçlardan da görüldügü gibi soruyu cevaplayan öğretmenlerin eşit bir dağılım gösterdiği söylenebileceği gibi her iki müziğgin aynı anda öğretilmesinde bir sakınca olmadığını söyleyenlerin bir miktar fazla oranda olduğu söylenebilir.

Öğretmenler, Türk müziği öğretimi ile ilgili akademik çalışmaların yetersiz olduğu görüşünü savunmaktadır (\%59,8 x̄: 2,47). Bunun nedenlerin başında Türk müziği ile ilgili henüz akademik anlamda da sistematik bir teori oluşturulamamasının geldiği düşünülebilir. Türk müziğinin öğretimi ve uygulamaları ile ilgili genel müzik eğitimini ilgilendiren çalışmalar yapılmamaktadır. Akademik anlamda çalışmalar genellikle mesleki müzik eğitimi üzerine olsa da, bu çalışmaların sayıları da oldukça azdır. Ayrıca öğretmenler Türk ve batı müziği öğretimi ile ilgili hizmet içi eğitimlere ihtiyaç duyduklarını beyan etmişlerdir $\% 83,9 \bar{x}: 4,09$. Öğretmenlerin büyük birçoğunun hizmet içi eğitim beklentilerinin olması bu alan ile ilgili güncel öğretim tekniklerine öğretmenler tarafından da ihtiyaç duyulduğunu göstermektedir.

Türk müziği öğretimi ile ilgili yeni sistematik bir yaklaşıma ihtiyacın olduğunu düşünen öğretmenlerin oranı \%78,6'dır ( $\bar{x}: 3.95)$. Bu sonuçlar Türk müziği öğretimi ile ilgili yeni bir öğretim modeline ihtiyaç duyulduğunu göstermektedir. Öğretmenler öğretim programının doğrultusunda öğrenimlerini gerçekleştirirler. Ancak bu sonuçlar göstermektedir ki öğretim programının da 
güncellenmesi ve yenilenmesi gerekmektedir. Öğrencilerin Türk müziği konularına ilgi düzeyleri ile ilgili soruya verilen cevaplar doğrultusunda öğrencilerin konulara ilgi düzeylerinin düşük olduğu gözlemlenmiştir ( $\mathrm{x}: 2,61)$. Türk müziği hayatımızın içinde olan, öğrencilerin çevrelerinden, yörelerinden yani doğal yaşamlarında da karşılarına çıkan önemli bir unsurdur. Bu durumda öğrencilerin konulara ilgisiz olmalarının nedeni öğretim programının uygulanışı ve çıktıları ile ilgili sorunlar olabildiği fikrini düşündürmektedir.

Müzik derslerinde okul çalgısı kullandırma durumlanını belirlemek için sorulan soruya, çalışmaya katılan öğretmenlerin büyük bir çoğunluğu olumlu cevap vermiştir. \%77 oranında öğretmen derslerinde okul çalgısı kullandıklarını belirtmiştir ( $\bar{x}: 3.74)$. Öğrenme alanları içerisinden çalg1 eğitimi çıkartılmış olsa da, öğretmenler derslerinde çalg1 öğretimi gerçekleştirmeye devam etmektedir. Bu sonuçlar göstermektedir ki çalgı öğrenme alanı öğretim programından çıkarılsa da hala öğretmenler için önemli bir öğrenme alanı olarak kullanılmaktadır. Blok flüt okul çalgıları arasında popülerliğini hala korusa da, ekonomik düzeyleri daha iyi durumda olan öğrencilerin bulunduğu okullarda, öğretmenler melodika, gitar, ukulele ve orff çalgıları ile çalgı öğretimini gerçekleştirmeye devam etmektedirler.

Sonuç olarak, çalışmaya katılan toplam 1321 öğretmenden alınan cevaplar doğrultusunda, Türk müziği ve çalgı öğretimi ile ilgili;

- Öğretim programının Türk müziği ile ilgili bölümlerinin yetersiz olduğu,

- Öğretmenlerin büyük bir çoğunluğunun Türk müziği çalgısı kullanamadığı,

- Blok flütün bir okul çalgısı olarak yeterli olmadığı ve Türk müziği ile tonal müziğin aynı anda çalınabileceği bir çalgıya ihtiyaç olduğu,

- Çalg1 öğretiminin öğretim programından kaldırılsa da hala öğretmenler tarafından sıklıkla kullanıldı $\breve{g} 1$,

- Öğretmenlerin koma sesi öğretirken zorluklar yaşadığı,

- Türk müziği öğretimi ile ilgili akademik çalışmaların yetersiz olduğu,

- Öğretmenlerin hizmet içi eğitimlere ihtiyaçlarının olduğu,

- Türk müziği öğretimi için yeni sistematik yaklaşıma ihtiyaç olduğu,

- Öğrencilerin Türk müziği konularına ilgi düzeylerinin düşük olduğu sonuçlarına varılmıştır.

\section{Öneriler}

Genel müzik eğitiminde Türk müziği öğretimi ve çalgı boyutu ile ilgili elde edilen bilgiler doğrultusunda, öğretim programında Türk müziği öğretimi ile ilgili bölümlerin yetersiz olduğu ve bu bölümlerin hem içerik hem de sayı olarak arttırılması gerektiği düşünülmektedir. Yaşadıkları çevre, katıldıkları etkinlikler düşünüldüğünde, öğrencilerin Türk müziği öğretimi ile ilgili konulara olan ilgi düzeylerinin düşük olması, öğretim yöntemleri ve programlama ile ilgili olduğu fikrini düşündürmektedir. Öğrencilerimizin Türk müziği ile ilgili konulara ilgi düzeylerini arttırmak için öğretim yöntem ve tekniklerimizi değiştirmek buna bağlı olarak da öğretim programını yeniden şekillendirilmesi gerekmektedir.

Çalışmaya katılan öğretmenlerin büyük bir çoğunluğunun Türk müziği öğretimi ve çalg1 eğitimi konularında hizmet içi eğitim taleplerinin olduğu saptanmıştır. Bu bağlamda, Türk müziği öğretimi ile ilgili öğretmenlerin seminer dönemlerin kapsayacak şekilde çeşitli aralıklarla hizmet içi eğitimler düzenlenmelidir. Bu eğitimlerin içeriği ve programlanması Milli Eğitim Bakanlığı ve Yüksek Öğretim Kurumu arasında gerçekleşecek protokoller ile sağlanarak, akademisyenlerin de programda öğretici olarak katılmaları sağlanmalıdır. 
2018 y1lında güncellenerek son halini alan ilköğretim ve ortaöğretim müzik dersleri öğretim programında öğrenme alanları arasında daha önceki yıllarda yer alan çalgı öğrenme alanı çıkartılmıştır. Çalg1 eğitiminin müzik eğitiminde önemini vurgulayan birçok çalışma vardır. Çalışmadan elde edilen bulgulara göre de öğretmenlerin büyük çoğunluğu derslerinde çalg1 öğretimine devam etmektedir. Çalgı öğrenme alanının tekrardan öğretim programının içerisine alınarak yenilenmesi gerekmektedir.

Formasyon eğitimi alarak müzik öğretmeni olmaya hak kazanan öğretmenlere, mezun oldukları programın ne olduğuna bakılmaksızın, herhangi bir Türk müziği enstrümanı çalabilmelerinin sağlanması gerekmektedir. Bu eğitim formasyon öğrencilerine müzik alanı eğitimi için zorunlu tutulabilir. Böylelikle müzik öğretmenliği kimliği kazanan tüm öğretmenlerin asgari düzeyde Türk müziği öğretimi için gerekli olan bir Türk müziği enstrümanı çalma becerisi sağlanabilir. Sınıf öğretmenlerinin müzik dersleri ile ilgili alan yeterlilikleri düzeylerinin düşük olması, ilkokul evresinde müzik derslerinin verimli geçmemesine neden olmaktadır. İlkokul döneminden itibaren müzik öğretmenlerinin derslerde olması, ilerleyen öğretim sürecinde ve Türk müziği öğretiminde katkı sağlayacağ düşünülmektedir.

Öğretim programının ilgili bölümleri yeniden gözden geçirilerek yenilenmesinin öğrenime katk1 sağlayacağı düşünülmektedir. Türk müziği öğretiminin ilk ve ortaöğretim seviyelerinde öğretimine yönelik akademik uzmanların yanında alan öğretmenlerinin de aktif olarak katılacağ1 çalıştaylar düzenlenmelidir. Bu çalışmalar sonucu ortaya çıkacak sonuçlar Milli Eğitim Bakanlığı ile paylaşılarak, ülke genelinde uygulanabilir bir öğretim yöntemi belirlenmelidir.

\section{Kaynakça}

Albuz, A. (2001). Viyola Eğitiminde Geleneksel Türk Müziği Ses Sistemine İlişkin Dizilerin Kullanımı Ve Bu Sistem Kaynaklı Çokseslilik Yaklaşımları. Yayınlanmamış Doktora Tezi. Gazi Üniversitesi Fen Bilimleri Enstitüsü.

Büyüköztürk, Ş. (2011). Sosyal Bilimler İçin Veri Analizi El Kitabı - İstatistik, Araştırma Deseni, Spss Uygulamaları ve Yorum (15. Bask1). Pegem Akademi.

Bozkaya, İ. (2001). Okul ortamında müzik. (Birinci Basım). Özsan Matbaacılık

Çakırer, H.S. Kınık, M. (2014). Güzel Sanatlar Fakülteleri Müzik Bölümlerinde Bağlama Dersi Başlangıç Düzeyi Öğretim Elemanları Görüşleri. Akdeniz Sanat Dergisi. 7(13),70-80

Çoban, S. (2011). Müzik öğretmeni adaylarının bireysel çalgı eğitimi dersi dönem sonu sınavları ile ilgili düşünceleri (Marmara üniversitesi örneği). Buca eğitim fakültesi dergisi. 31, $115-127$.

Ekici, T. (1998). Orff Çalgıları ve Müzik Eğitiminde Kullanım Yöntemleri. Yüksek Lisans Tezi. https://tez.yok.gov.tr adresinden erişilmiştir.

Karasar, N. (1998). Bilimsel Araştırma Yöntemi. Nobel

Karataş, Y. Kılıç, I. (2017). Ortaöğretim Düzeyi Müzik Derslerinde Kullanılan Okul Çalgıları ve $\mathrm{Bu}$ Çalgıların Öretilmesinde Karşılaşılan Sorunların İncelenmesi. Adiyaman Üniversitesi Sosyal Bilimler Enstitüsü Dergisi, 26, 565-601.

Kaya, M.F. (2013). Sürdürülebilir Kalkınmaya Yönelik Tutum Ölçeği Geliştirme Çalışması. Marmara Coğrafya Dergisi, 28,175-193.

Kurtasan, H. Koca, Ş. (2013). Sınıf Öğretmeni Adayların Müzik Dersleri Kapsamında Aldıkları Blokflüt Eğitimine Yönelik Bakış Açıları. Ĕğitim ve Öğretim Araştırmaları Dergisi, 2, (4) 145-151. 
Kocabaş, A. (2000). Sınıf Öğretmenlerinin Müzik Derslerindeki Yetersizliklerine İlişkin Görüşleri. Pamukkale Üniversitesi Eğitim Fakültesi Dergisi. 7(7), 7-11.

MEB (2018). Müzik dersi öğretim programı 1, 2, 3, 4, 5, 6, 7,8.sınıflar.

MEB (2018). Müzik dersi öğretim programı 9, 10, 11, 12. sınıflar.

Özen, N. (2004). Çalgı Eğitiminde Yararlanılan Müzik Eğitimi Yöntemleri. Gazi Ĕgitim Fakültesi Dergisi. 24 (2). 54-63.

Peach, Harold. (2017). Calculates Lawshe Content Validity Ratios (CVR) for an item and a Content Validity Index (CVI) value for the overall instrument. https://www.youtube.com/watch?v=GtdtOqbNgOA adresinden erişilmiştir.

Şen, Y. (2016). SPSS ile 2'den Fazla Grup Karşılaştırılması ANOVA. https://sedatsen.files.wordpress.com/2016/11/3-sunum.pdf adresinden erişilmiştir.

Uçan, A. (2005). Müzik Eğitimi. Evrensel.

Yıldız, D. Uzunsakal, E. (2018). Alan Araştırmalarında Güvenirlik Testlerinin Karşılaştırılması ve Tarımsal Veriler Üzerine Bir Uygulama. Uygulamall Sosyal Bilimler Dergisi, 1, 14-28.

YÖK (2018). Müzik Öğretmenliği Lisans Programı. https:// www.yok.gov.tr /Sayfala Kurumsal IdariBirimler/egitim_ogretim_daire_bsk/S\%C4 \%B0L\%C4\%B0NECEKyeni_ogretmen_ yetistirme_lisans_programi/ogretmen_yetistirme_lisans_programi.aspx 